Dikirim: 27 Desember 2016 Diterbitkan: 1 April 2017

\title{
Pengalaman hidup ibu dengan riwayat kehamilan preeklamsia di Yogyakarta
}

\section{Life experience of mothers with preeclampsia pregnancy history in Yogyakarta}

Maulida Rahmawati Emha ${ }^{1}$, Elsi Dwi Hapsari ${ }^{2}$, Wiwin Lismidiati²

\begin{abstract}
Purpose: The purpose of this paper was to determine the life experience of women with pre-eclampsia pregnancy history. Methods: This research was a phenomenology study involving 7 postpartum mothers with history of pregnancy and delivery of preeclampsia in Dr. Sardjito Hospital conducted from June to September 2015. Results: Based on this research, there were 4 themes which were found: 1 . the symptoms that are felt to affect the psychological, spiritual, physical and behavior of the mother; 2. Awareness raising; 3. Source of power from family and community; and 4. Anxiety and fear have an impact on the mother's perception during the process of referral and childbirth. Conclusion: This study contributes to the knowledge that maternal conditions with preeclampsia pregnancy and childbirth in Yogyakarta still require the attention of health workers, especially from the aspects of alertness to perceived symptoms and the importance of information about pregnancy preeclampsia.
\end{abstract}

Keywords: preeclampsia; postpartum mother; life experience

\footnotetext{
${ }^{1}$ Departemen Keperawatan Maternitas, Fakultas Kedokteran, Universitas Gadjah Mada (Email: nida.solihah@gmail.com)

${ }^{2}$ Program Studi Ilmu Keperawatan, Fakultas Kedokteran, Universitas Gadjah Mada
} 


\section{PENDAHULUAN}

Preeklampsia merupakan suatu kondisi spesifikkehamilan dengan hipertensi terjadi setelah minggu ke-20 pada wanita yang sebelumnya memiliki tekanan darah normal. Ibu dengan riwayat kehamilan dengan preeklampsia akan mengalami stressor yang lebih besar dibandingkan dengan kehamilan normal. Preeklamsia merupakan suatu penyakit vasospastik, yang melibatkan banyak sistem dan ditandai oleh hemokonsentrasi, hipertensi, dan proteinuria. Diagnosis preeklamsia secara secara tradisional didasarkan pada adanya hipertensi yang disertai proteinuria atau edema (1).

Millennium Development Goal's (MDG's) 2015 terdiri dari delapan tujuan jangka panjang, salah satunya meningkatkan kesehatan ibu dengan target penurunan angka kematian ibu mencapai 108/100.000 kelahiran hidup. Di akhir tahun 2013 angka kematian ibu (AKI) menurut Survei Demografi dan Kesehatan Indonesia berada pada angka 359/100.000 kelahiran hidup, jauh meningkat dari data akhir SDKI (2007) dengan AKI sebesar 228/100.000 kelahiran hidup (2). Menurut World Health Organization (WHO) setiap tahun di seluruh dunia, lebih dari 500.000 wanita meninggal disebabkan karena komplikasi kehamilan dan persalinan dan hampir secara keseluruhan terjadi di negara berkembang (3). Epidemiologi pada kehamilan dengan komplikasi preeklamsia di negara barat mencapai 3-8\% kehamilan (4).

Berbagai penyebab AKI di Indonesia meliputi komplikasi perdarahan, infeksi, keracunan kehamilan, kondisi pada saat kehamilan, pertolongan persalinan yang aman, dan perawatan bayi baru lahir (2). Intervensi terhadap faktor-faktor telah banyak diupaya- kan dari sisi kedokteran, namun yang menjadi masalah, adalah faktor lain seperti tingkat pendidikan ibu yang rendah, keadaan sosial budaya tidak mendukung, status gizi ibu hamil rendah (40\% dari ibu hamil menderita anemia) atau status kesehatan yang tidak baik.

Tahun 2009-2011 di RS Sardjito Yogyakarta berdasarkan data rekam medis, jumlah kasus preeklampsia sebanyak 277 kasus. Penurunan kondisi ibu yang mengalami preeklamsia sampai dengan kejadian eklamsia sangat berhubungan dengan stres psikologis dan peningkatan tanda dan gejala eklamsia (5). Studi literatur yang telah didapatkan penulis menunjukkan bahwa penelitian kuantitatif tentang preeklamsia yang menjabarkan tentang penanganan, penyebab, dan penatalaksanaan medis sudah banyak, namun penelitian yang melihat dari perspektif ibu yang ditulis secara ilmiah melalui studi kualitatif masih sedikit $(6,7,8)$. Padahal, hasil penelitian kualitatif diharapkan bermanfaat bagi pelaksana pelayanan kesehatan dalam memahami ibu hamil dengan kondisi preeklamsia khususnya di wilayah Daerah Istimewa Yogyakarta (DIY). Penelitian ini bertujuan untuk mengetahui pengalaman hidup ibu dengan riwayat kehamilan preeklampsia.

\section{METODE}

Penelitian ini merupakan penelitian kualitatif dengan pendekatan fenomenologi (9). Penelitian ini dilaksanakan di masyarakat Yogyakarta dengan budaya jawa dan memiliki permasalahan kehamilan dan persalinan dengan preeklamsia. Penelitian dilaksanakan bulan Juni sampai dengan September 2015. Partisipan adalah adalah ibu yang mengalami preeklampsia yang telah bersalin atau dalam masa nifas. Penelitian dimulai segera setelah persalinan agar diketahui perubahan adaptasi fisiologis yang terjadi dan juga pengalaman tentang kehamilan berisiko tersebut dan upaya yang telah dilakukan selama kehamilan, persalinan dan peran serta dukungan keluarga, masyarakat dalam lingkup pengalaman ibu.

Teknik pengambilan partisipan secara purposive sampling. Instrumen yang digunakan dalam penelitian adalah pedoman wawancara dan alat perekam suara. Pengumpulan data dilakukan di rumah partisipan yang diikuti 7 partisipan ibu. Wawancara mendalam dilakukan sebanyak 1-2 kali. Durasi wawancara mendalam 20-30 menit. Saturasi data pada partisipan ke-7. Keabsahan data (trustworthiness) dengan triangulasi sumber dan metode serta member checking. Pengolahan data menggunakan bantuan program open code 3.6 B1, kemudian data dianalisis dengan metode Colaizzi dengan menentukan kata kunci, koding, dan tema dari naskah transkrip. Permohonan ethical clearance dari komite etik Fakultas Kedokteran Universitas Gadjah Mada.

\section{HASIL}

Total partisipan dalam penelitian ini sebanyak 7 orang merupakan penduduk Yogyakarta yang mengalami preeklamsia-eklamsia dan telah memenuhi kriteria inklusi yang telah ditetapkan. Semua partisipan merupakan warga asli suku Jawa dan bertempat tinggal di Yogyakarta, engan tempat tinggal yang tersebar dari Gunung Kidul sampai dengan Sleman, partisipan mengalami tekanan darah tinggi pada kehamilannnya dan dirujuk ke RS Sardjito. 
Karakteristik ketujuh partisipan meliputi: P1 merupakan ibu rumah tangga yang membuka salon di rumah, dengan kondisi hamil anak ke-3 di usia 35 tahun. Partisipan mengalami preeklamsia pertama kali; P2 merupakan ibu rumah tangga yang tinggal masih di kawasan desa mengalami preeklamsia di kehamilan ketiga dan merasakan perbedaan yang sangat berat dibanding kehamilan sebelumnya, dan dari keluarga golongan ekonomi rendah. Partisipan sangat cemas dengan kehamilannya dengan kondisi berat badan bayi yang kurang dari normal; P3 merupakan ibu rumah tangga yang aktif di dalam kegiatan kemasyarakatan, dan merasakan dukungan yang begitu besar dari keluarga dan masyarakat sehingga dapat melewati keadaan sulit kehamilan dengan baik dan penuh rasa syukur; P4 adalah seorang ibu muda yang melahirkan di usia yang sangat muda, sangat pendiam dan lebih banyak memperhatikan kedua orang tuanya saat menjawab pertanyaan; P5 merupakan ibu rumah tangga yang bersyukur dengan pernikahan keduanya, mengalami proses persalinan yang panjang karena harus dirujuk 3 RS besar di Yogyakarta dikarenakan mimisan sepanjang waktu rujukan. Rasa takut akan ancaman kematian yang mendalam dirasakan partisipan, dan rasa syukur yang besar ketika bayi telah lahir selamat; P6 adalah seorang guru yang aktif dengan kondisi obesitas, yang tidak percaya dengan kehamilannya dan merasa sangat takut apakah dapat menjaga bayinya sampai lahir dengan selamat; P7 merupakan ibu rumah tangga yang sebelumnya belum pernah mengalami preeklamsia pada kehamilan sebelumnya, merasakan bahwa keputusan yang berat harus melahirkan anaknya sebelum waktu kelahiran. Dalam penelitian ini ditemukan 4 tema yang mendeskripsikan pengalaman ibu dengan preeklamsi-eklamsia di Yogyakarta.

\section{Tema 1: Gejala yang dirasakan memengaruhi psikologis, spiritualitas, fisik, dan perilaku ibu.}

Terdapat 9 kategori yang dikemukakan partisipan tentang gejala yang dirasakan selama kehamilan dan persalinan dengan keadaan preeklamsia-eklamsia.

“ biasa mbak, mual muntah. Kadang pusing tapi saat periksa awal tekanan darah normal.“(P2)

Gejala preeklamsia akan muncul pada saat trimester kedua atau ketiga dengan gejala pusing ketika tekanan darah meningkat dan kaki membengkak. "saya merasa lebih sering pusing dan pandangan mata mulai sedikit kabur pandangan, tidak jelas. Lalu, kaki saya makin bengka.” (P2)

Gejala psikologis partisipan berupa rasa cemas dan ketakutan pada kehamilan preeklamsia lebih tinggi akan keselamatan anak yang dikandung dan meningkat setelah di diagnosis preeklampsia.

"Pertama kali senang, tapi ya merasa ketakutan tapi senang. seperti trauma dari melahirkan yang kedua itu” (P7)

Secara spiritualitas, partisipan dengan kehamilan preeklamsia lebih baik dan berusaha untuk pasrah terhadap takdir dan memohon keselamatan kepada Tuhan yang maha kuasa :

" saat itu hanya bisa berdoa. Maksudnya, semua yang menentukan yang Di Atas, jadi sudah pasrah ...” (P1)

\section{Tema 2: Peningkatan Kewaspadaan.}

Partisipan menyampaikan pengalaman tentang kewaspadaan dan kekhawatiran akan gejala yang tampak sebagai indikator tanda bahaya dan harus segera kontrol ke dokter atau pelayanan kesehatan, dengan 3 kategori yang dapat menjelaskan apa yang dirasakan oleh partisipan.

"Ibu saya selalu bertanya apakah saya sudah periksa belum bulan ini? Bapak yang selalu mengantar ke puskesmas.” (P3)

"ya khawatir saja, diminta untuk sering periksa, sering makan, banyak istirahat, tidak boleh terlalu banyak berpikir, tapi kalau saya takut, ya tekanan darah naik terus.” (P7)

Partisipan menyatakan bahwa ada perbedaan proses kehamilan dan persalinan yang dialami dengan kehamilan sebelumnya, karena peningkatan tekanan darah tinggi, baik secara fisik maupun secara psikologis. Hal ini diungkapkan partisipan dalam pernyataan berikut:

"ya jelas-jelas berbeda, dulu tidak pernah seperti ini, ada hipertensi, keluhan lain saat diperiksa. Kalau dulu tidak, hanya berkata sehat, ya sudah. Ini membuat jadi pikiran juga” (P1) 


\section{Tema 3: Sumber Kekuatan dari Keluarga dan Masyarakat.}

Keluarga partisipan menyampaikan berbagai pengalaman terkait dukungan pada partisipan yang terkait dengan preeklampsia atau eklampsia. Keluarga yang aktif memberikan dukungan akan memberikan kekuatan tersendiri pada partisipan. Hal ini diungkapkan partisipan dalam pernyataan berikut:

\section{"Suami saya paling menguatkan saya.” (P2)}

"semua mendukung saya. Jadi semangatnya dari mereka. Mungkin mereka juga khawatir, bagaimanapun juga saya seorang anak, istri, tapi semua orang berdoa, jadi alhamdulilah selamat semua.” (P6)

Dukungan masyarakat sangat memengaruhi kondisi ibu dansemangat ibu dalam memperhatikan perkem- bangan persalinan dan kehamilannya.

"tetangga mbak, maksudnya, ya mereka banyak memberi tahu, hati-hati kalau hamil kerja dikurangi." (P3)

\section{Tema 4: Cemas dan takut berdampak pada persepsi ibu selama proses rujukan dan persalinan.}

Partisipan menyampaikan tentang perasaan takut dan kecemasan yang dialami selama proses kehamilan dan persalinan. Tema 4 ini dijelaskan dalam 2 kategori. Kecemasan partisipan akan kehamilan dan persalinan yang dialami dapat tertuang dalam pernyataan berikut.

\section{“pokoknya takut kalau melahirkan kemarin itu” (P1)}

Empat partisipan mengungkapkan kecemasan tentang perawatan bayi yang membutuhkan perawatan ekstra karena berat badan yang kurang dari normal. Hal ini diungkapkan partisipan dalam pernyataan berikut:

"ya sebisa mungkin saya disini bersama anak, karena pasti anak belum boleh pulang (nangis) tetap inginnya ya memberi asi terus ya mbak, agar cepat pulang.” (P6)

\section{BAHASAN}

Gejala yang dirasakan memengaruhi aspek psikologis, spiritualitas fisik, dan perilaku.

Ibu hamil dengan kondisi preeklampsia-eklampsia menyampaikan bahwa mereka merasakan gejala normal kehamilan pada awal-awal kehamilan dan akan muncul peningkatan tekanan darah pada trimester 2 dan trimester 3 disertai dengan rasa pusing di kepala, pandangan kabur dan kaki membengkak. Preeklamsia adalah kehamilan dengan sindrom spesifik yang biasanya muncul setelah 20 minggu kehamilan dan ditentukan dengan adanya gestasional hipertensi ditambah proteinuri (10).

Secara psikologis persalinan fisiologis normal dapat menimbulkan trauma dan ketidaknyamanan pada ibu, apalagi disertai dengan peningkatan tekanan darah yang dapat berdampak pada kematian ibu dan janin, hal ini akan memicu stres pada ibu yang akan berdampak pada adaptasi ibu terhadap keadaan kehamilan. Menurut Harris JM dkk., ibu dengan preeklamsia di amerika memiliki 2 tipe koping psikologis yang diterapkan dalam mengatasi stres meliputi manajemen bahaya (danger managers), ibu memiliki kontrol internal dengan fokus terhadap risiko preeklamsia dan berusaha mencari informasi tentang apa yang dibutuhkan, perubahan gaya hidup positif dan menilai kembali koping mekanisme yang dipakai selama ini (11). Tipe yang kedua adalah manajemen takut.bu memiliki kontrol eksternal dengan fokus terhadap risiko preeklamsia yang muncul pada perkembangan janin dan melakukan koping mekanisme menghindar (exhibit avoidance coping mechanisms). Dari penjelasan di atas, sebagian besar partisipan memiliki tipe psikologis kedua, dengan partisipan lebih mengedepankan manajemen rasa takut dibandingkan dengan manajemen tanda bahaya.

Secara spiritual, partisipan merasa sangat pasrah dan banyak berdoa untuk keselamatan ibu dan bayi. Peningkatan spiritualitas ini sangat mendukung penerimaan ibu terhadap keadaan kehamilan dan proses persalinan dan peningkatan penerimaan rasa syukur. Penelitian Souza NL et al, (2007) tentang persepsi maternal pada kelahiran premature dan pengalaman kehamilan preeklamsia yang menggunakan fokus grup diskusi (FGD) mengungkapkan bahwa terdapat laporan yang menunjukkan bahwa terdapat faktor yang berhubungan dengan agama (spiritual) dalam penerimaan situasi dan keadaan (12). Hubungan antara religiusitas atau spiritualitas dan kecemasan umumnya tidak dipahami dengan baik. Sebuah tinjauan literatur tentang religiusitas dan kecemasan oleh Shreve-Neiger dan Edelstein (2004) menemukan bahwa kehadiran agama dan orientasi religius intrinsik (melihat agama sebagai kerangka dengan semua kehidupan dipahami) yang umumnya terkait dengan tingkat yang lebih rendah dari kecemasan (13). 


\section{Peningkatan Kewaspadaan.}

Data penelitian menunjukkan bahwa gejala kepala pusing, kaki semakin membengkak dan pandangan kabur merupakan gejala yang dirasakan ibu sebagai peringat- an tanda bahaya yang harus segera diperiksakan ke dokter dan mendapatkan informasi untuk beristirahat dan mengurangi konsumsi garam. Menurut WHO, (2007) diagnosis preeklamsia berat adalah jika kriteria tekanan darah diastolik 110 dengan proteinuria 3+ atau lebih dan memiliki salah satu atau lebih gejala penyerta yaitu sakit kepala, pandangan berputar, urine sedikit kurang dari $400 \mathrm{ml}$, epigastric atau nyeri pada perut kanan atas dan edema paru. Hasil penelitian ini tidak sesuai dengan hasil yang didapatkan pada penelitian Souza NL, (2007) yang mengungkapkan bahwa terdapat ketidakwaspadaan ibu terhadap kondisi selama perawatan kehamilan dan akan meningkat setelah ibu masuk rumah sakit dan me- nyadari bahwa kehamilannya merupakan kehamilan dengan risiko tinggi (12).

Peningkatan kewaspadaan ibu selama kehamilan preeklamsia dan upaya yang dilakukan untuk mencari informasi tentang tekanan darah tinggi pada kehamilan, mendukung penelitian JM. Harris et al (2014), terdapat koping strategi yang dilakukan ibu ketika disampaikan informasi tentang kehamilannya berisiko tinggi, seperti: 1 . mencari informasi lebih lanjut (umumnya dari pencarian internet), bagaimana pre-eklampsia bisa memengaruhi mereka. 2. mengubah perilaku menjadi perilaku kesehatan positif seperti: perubahan pola makan, lebih banyak latihan dan kegiatan untuk mengurangi stres (11). Hal serupa juga dijelaskan dalam Helson dalam Tomey AM dan Alligood MR, bahwa stimulus diperlukan untuk membentuk respon adaptif sampai derajat adaptasi yang dibutuhkan individu tercapai (14).

Sumber kekuatan dari keluarga masyarakat. Hasil penelitian menunjukkan terdapat peranan yang sangat penting dari suami, orang tua, dan tetangga (masyarakat) dalam memberikan dukungan positif dan penjagaan terhadap gejala serta keluhan yang dirasakan. Dukungan keluarga dan masyarakat akan meningkatkan kekuatan ibu dalam menghadapi kondisi persalinan. Hal ini sesuai dengan penjelasan Roy dalam Alligood MR (2010) bahwa sistem adaptif manusia dijelaskan sebagai suatu sistem yang hidup, terbuka dan adaptif yang dapat mengalami kekuatan dan zat dengan perubahan lingkungan dengan adanya stimulus (15). Manusia menunjukkan interdependensi sebagai suatu sistem. Model interdependensi adalah interaksi untuk saling memberi dan menerima cinta/kasih sayang, perhatian dan saling menghargai, meliputi keseimbangan antara ketergantungan dan kemandirian dalam menerima sesuatu untuk dirinya. Ketergantungan ditunjukkan dengan kemampuan untuk afiliasi dengan orang lain. Ketergantungan ibu dalam hasil penelitian ini dapat bersifat keseluruhan maupun sebagian, bagi ibu yang mengalami persalinan dengan section Caesar maka ketergantungan terhadap keluarga akan lebih besar setelah persalinan dan dalam merawat bayi di minggu-minggu pertama kehidupan. Ibu dengan persalinan normal dan multipara maka memberikan perawatan pada bayi dengan mandiri. Menurut Alligood MR (2010) kemandirian ditunjukkan oleh kemampuan berinisiatif untuk melakukan tindakan bagi dirinya (15).

Cemas dan Takut berdampak pada persepsi ibu selama Proses Rujukan dan Persalinan. Data yang diungkapkan partisipan menunjukkan terdapat kecemasan dan ketakutan yang sangat berdampak pada peningkatan tekanan darah selama proses kehamilan dan persalinan. Hal ini sama seperti apa yang diungkapkan Harris JM bahwa strategi koping akan meningkatkan monitoring pada ibu untuk melakukan pengecekan kesehatan selama kehamilan (11). Pada konsep Roy hal ini termasuk dalam personal self yang berkaitan dengan konsistensi diri, ideal diri, moral-etik dan spiritual diri orang tersebut. Perasaan cemas, kekuatan yang hilang atau takut merupakan hal yang berada dalam area ini (15).

Ketakutan terkait kehamilan dan persalinan adalah pengalaman psikologis perempuan yang umum terjadi selama kehamilan dan prevalensi ketakutan tersebut telah meningkat selama dekade terakhir. Pada penelitian Eriksson, C., Westman, G., \& Hamberg, K. $80 \%$ wanita hamil dengan risiko rendah mengalami berbagai tingkat ketakutan pada saat melahirkan (16). Wanita dengan kehamilan risiko tinggi memiliki tingkat ketakutan yang lebih tinggi, terlihat pada pengalaman takut operasi caesar darurat (SC), permintaan SC elektif, serta menderita tingkat depresi nifas yang cenderung lebih tinggi. asa sakit yang lebih besar dan kesusahan juga dialami selama persalinan.

\section{SIMPULAN}

Penelitian menyimpulkan gejala yang dirasakan memengaruhi psikologis, spiritual, fisik dan perilaku ibu dengan riwayat kehamilan preeklampsia. Perlu peningkatan kewaspadaan selama kehamilan dengan riwayat preeklampsia. Sumber kekuatan ibu didapatkan dari keluarga dan masyarakat. Cemas dan 
takut berdampak pada persepsi ibu selama proses rujukan dan persalinan.

Perawat hendaknya mampu memahami gejala yang dialami ibu dengan kehamilan preeklamsia sehingga dapat mendeteksi secara dini untuk mencegah komplikasi. Perawat diharapkan dapat memberikan dukungan positif terhadap kecemasan dan ketakutan yang muncul sehingga tidak menjadi respon maladaptif.

Keluarga diharapkan mampu memperhatikan ibu dengan riwayat kehamilan pereeklamsia untuk mengetahui gejala yang membahayakan ibu dan janin. Perlu pengembangan penelitian lebih lanjut terhadap dampak psikologis terhadap kehamilan preeklamsia dan hubungan terhadap dukungan spiritualitas.

\footnotetext{
Abstrak

Tujuan: Penelitian ini bertujuan untuk mengetahui pengalaman hidup ibu dengan riwayat kehamilan pre-eklampsia. Metode: Studi fenomenologi melibatkan 7 ibu post-partum dengan riwayat kehamilan dan persalinan preeklampsia di RSUP dr. Sardjito yang dilaksanakan pada bulan Juni sampai dengan September 2015. Hasil: Berdasarkan penelitian ini didapatkan 4 tema yaitu: tema 1 . gejala yang dirasakan memengaruhi psikologis, spiritual, fisik dan perilaku ibu; tema 2. Peningkatan kewaspadaan; tema 3. Sumber kekuatan dari keluarga dan masyarakat; tema 4. Cemas dan takut berdampak pada persepsi ibu selama proses rujukan dan persalinan. Simpulan: Penelitian ini memberikan kontribusi pengetahuan bahwa kondisi ibu dengan kehamilan dan persalinan preeklamsia di Yogyakarta masih membutuhkan perhatian tenaga kesehatan terutama dari aspek kewaspadaan terhadap gejala yang dirasakan dan informasi tentang kehamilan preeklampsia.
}

Kata Kunci: preeklamsia; ibu postpartum; pengalaman hidup

\section{PUSTAKA}

1. Bobak, I., Deitre M. \& Shannon.Maternity Nursing. Mosby Year Book, St Louis. 2005.

2. SDKI, 2012, Laporan Pendahuluan Survei Demografi dan Kesehatan Indonesia, BPS dan

3. BKBN dan Kementrian Indonesia, Jakarta.WHO, 2008, Education material for teachers of midwifery Midwifery education modules - second edition Managing eclampsia, WHO.

4. Uzan J., et al, 2011, Pre-Eclampsia: Pathophysiology, Diagnosis, And Management, Vascular Health and Risk Management, diakses pada tanggal 11 maret 2014.

5. Black, KD.(2007). Stress, Symptoms, Self-Monitoring Confidence, Well-Being, and Social Support in the Progression of Preeclampsia/Gestational Hypertension, JOGNN Clinical Research, the Association of Women's Health, Obstetric and Neonatal Nurses, diakses pada tanggal 10 Maret 2014.

6. Duley, L., et al. (2012). Altered dietary salt for preventing pre-eclampsia, and its Complications, The Cochrane Collaboration, diakses pada tanggal 27 Maret 2013.

7. Meltzer, HM., et al.(2011). Effect of dietary factors in pregnancy on risk of pregnancy complications: results from the Norwegian Mother and Child Cohort Study, AMJ Clinical Nutrition, diakses pada tanggal 27 Maret 2013.

8. Thangaratinam, S, et all.(2012). Effects of interventions in pregnancy on maternal weight and obstetric outcomes: meta-analysis of randomised evidence, BMJ, diakses pada tanggal 27 Maret 2013.

9. Emzir. (2010). Metodologi Penelitian Kualitatif: Analisis Data. Jakarta: Rajawali Pers.

10. Perry, et al, 2010, Maternal Child Nursing Care,Fourth Edition, Canada: Mosby Elsevier.

11. Harris JM., Frank L., Green B., et al. (2014) The psychological impact of providing women with

12. risk information for pre-eclampsia: A qualitative study. Midwifery 30 (2014) 1187-11951188. Diakses pada tanggal 09 januari 2015.

13. SouzaNL., Araujo ACPF., Azedevo GD., et al (2007) Maternal perception of premature birth and the experience of pre-eclampsia pregnancy. Rev Saúde Pública. 2007:41(5). Diakses tanggal 09 januari 2015.

14. Shreve-Neiger AK, Edelstein BA.(2004). Religion and anxiety: a critical review of the literature. Clin Psychol Rev 24: 379-39.

15. Tomey AM. Dan Alligood MR.(2010). Nursing Theorists and Their Work, seven edition, United State of America, Mosby Elsevier.

16. Alligood, MR.(2010). Nursing Theory Utilization and Applicatio, Fourth Edition, United State of America: Mosby Elsevier.

17. Eriksson, C., Westman, G., \& Hamberg, K. (2006). Content of childbirth-related fear in Swedish women and men-analysis of an 1128 Matern Child Health J 19:1121-1130 123. 